39 (6) : 687 697, 1989

\title{
実験的心筋梗塞における梗塞巣の広がりと プロプラノロールの影響
}

\author{
大島茂 \\ 群馬大学医学部第二内科学教室（主任：村田和彦教授）
}

(平成元年 8 月 29 日受付, 平成元年 9 月 14 日 採択)

CCUの普及, xylocaine をはじめとする種々の抗 不整脈薬の登場によって不整脈死が激減した結果, 現在，心筋梗塞急性期における合併症の中では，心 ポンプ不全への対策が最も重要な問題となってい る. 心ポンプ不全の出現は心筋梗塞量に比例するも のであり ${ }^{1,2}$, その防止のため, 種々の薬物により心 筋梗塞巣を縮小させる試みが Maroko ら ${ }^{3,4)}$, Braunwald ら5) をはじめとする多くの研究者によって行 なわれてきた。

$\beta$ 遮断薬は心筋酸素需要を減じ，心筋虚血を改善 することが知られており, 狭心症の治療のみならず, 最近では急性心筋梗塞にも試みられている ${ }^{6 \sim 8)}$. しか し，その臨床効果については必ずしも意見の一致を みていない. その原因として, 虚血障害の程度およ び虚血障害の持続時間が問題となっている.

一方，梗塞巣の縮小が可能であるためには，閉塞 した冠動脈の灌流域内に可逆的な虚血障害領域, す なわち, border $z o n e^{9,10)}$ の存在することが前提とな る. 梗塞発症後の梗塞巣及び border zone の広がり については，これまで主としてイヌについて検討さ そてきたが9,11 13), 冠動脈分布に比較的個体差の少 䧇いラットを用いた方がより明確な成績が得られる 可能性がある.そこで著者は，ラットの冠動脈を閉 塞して実験的心筋梗塞を作成し, 梗塞巣及び border zone の広がりの時間的経過，また，これに対する $\beta$ 媇断薬 propranolol の影響を検討し, 若干の知見を 得たので報告する。

\section{対象および方法}

体重200～300gの雄 Wistar ラット84頭を用い, [実験 I ] では冠動脈閉塞後の心筋梗塞巣, border zone の広がりの時間的経過を，[実験II］ではこれ に対する propranolol の影響を検討した。なお，心
筋梗塞は, ラットを pentobarbital $(40 \mathrm{mg} / \mathrm{kg})$ の腹 腔内投与にて麻酔した後, 気管内挿管し, 人工呼吸 (呼吸数60回/分) 下に, Selye ${ }^{14)}$ の方法に準じて 左第 $4 \sim 5$ 肋間で開胸, 左冠状動脈を 5-0 絹糸で結 紮して作成した。

[実験 I] 24頭のラットを 8 頭づつ 3 群に分け， I 群は結禁 3 時間後, II群は 6 時間後, III群は12時 間後に pentobarbital 麻酔下にて屠殺した. 各群の 5 頭は, 麻酔後大腿静脈より methylene blue $1 \mathrm{ml} /$ $\mathrm{kg}$ を約 30 秒で注入した後, ただちに心臓を摘出し た. 摘出した心茞は房室間溝に平行に $2 \mathrm{~mm}$ 間隔で 横切, 4 分割した. 各横切片は写真撮影し, 図 1 の ごとく methylene blue 不染領域, すなわち area at risk の領域を planimeter を用いて計測した. なお， area at risk の大きさは, 図 1 のごとく, 3 枚のス ライスにおける area at risk の面積の和を中隔を含 む左室壁の面積の和で除して求め，\%LV (\% Left Ventricle) で示した. 写真撮影後, 各スライスに NBT (nitro-blue tetrazolium) 染色 ${ }^{15)}$ を施し, 再び
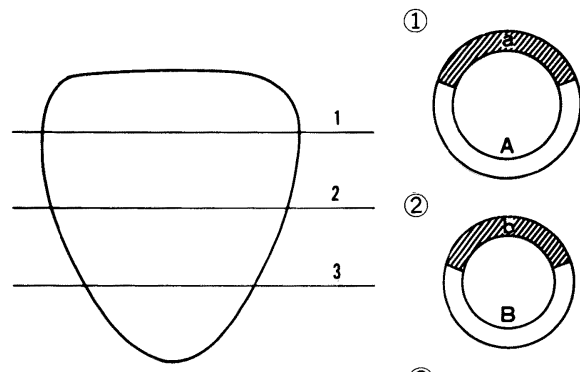

(3)

Area at riskの大きさ $(\% \mathrm{LV})=\frac{a+b+c}{A+B+C} \times 100$

$$
\begin{aligned}
& \text { A.B.C 左室壁の面積 } \\
& \text { a.b.c Area at riskの面積(斜線部) }
\end{aligned}
$$

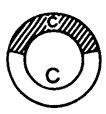

図 1 Area at risk の大きさ 
写真撮影して梗塞巣の面積を計測し, methylene blue 不染領域，すなわち， area at risk の領域と梗 塞領域の差を非梗塞虚血領域，すなわち border zone とした (図 2).

各群の残りそれぞれ 3 頭は, NBT 染色後, 梗塞 巣, border zone, 正常域に相当する部分よりそれぞ れ試料を採取し,電顕標本に供した。電顕試料は $3 \%$ グルタールアルデヒド及び $1 \%$ オスミウム酸にて固 定後，アルコール系列で脱水し，エポンに包埋した。

[実験II ] propranolol を腹腔内に投与したA 〜 Eの 5 群と対照群の各群について, それぞれ 10 頭 づつのラットを使用した。すなわち，A群には冠動 脈結禁前，B群には結禁直後，C群には 3 時間後, $\mathrm{D}$ 群には 6 時間後， E 群には12時間後に，それぞれ propranolol $5 \mathrm{mg} / \mathrm{kg}$ を腹腔内に投与した。また， 対照群には結紮前に生理食塩水 $5 \mathrm{ml} / \mathrm{kg}$ を投与し た. 各群とも結惄 24 時間後に propranolol または生 理食塩水を同量追加投与した。（表 1)

$\mathrm{A} \sim \mathrm{E}$ 群，対照群とも結禁 48 時間後に屠殺して心 臓を摘出，心室を [実験 I ] と同様に 4 分割した。 分割後, NBT 染色を施し, 写真撮影して, [実験 I ] と同様，梗塞巣の大きさを中隔を含む左室壁に占め る割合として求めた。また, 各群とも冠動脈結禁前,

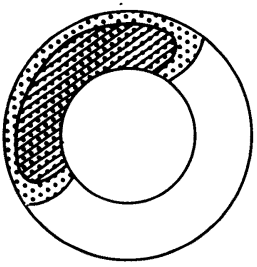

area at risk (Methylene blue不染部)

図 2 健常部，虚血部 (border zone)，梗塞部の模式図

表 1 propranolon (pr) 投与のプロトコール

\begin{tabular}{|c|c|c|c|c|}
\hline 群 & 頭数 & 投 & 与 & 法 \\
\hline A & 10 & \multicolumn{3}{|c|}{ 結禁前 $\operatorname{pr} .5 \mathrm{mg} / \mathrm{kg}$ (ip) + 24時間後同量 } \\
\hline B & $m$ & \multicolumn{2}{|l|}{ n直後 } & n \\
\hline $\mathrm{C}$ & $m$ & 1) 3 時間後 & & 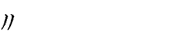 \\
\hline $\mathrm{D}$ & $m$ & 1) 6 時間後 & & $m$ \\
\hline $\mathrm{E}$ & $m$ & \multicolumn{2}{|l|}{ 川 12 時間後 } & $m$ \\
\hline 対照 & m & \multicolumn{3}{|c|}{$\begin{aligned} \text { 結紮前 生食水 } 5 \mathrm{ml} / \mathrm{kg} \\
\quad+24 \text { 時間後生食水 } 5 \mathrm{ml} / \mathrm{kg}\end{aligned}$} \\
\hline
\end{tabular}

結紮直後，および48時間後に，心電図 (肢誘導, CR 誘導）を $100 \mathrm{~mm} / \mathrm{sec}$ の記録速度で記録した。

結果は平均土標準偏差で示した。また，各群の比 較は Student's t-test で行ない，危険率 $5 \%$ 以下を 有意とした。

\section{結果}

[実験 I ] 心筋梗塞巣, border zone の広がり の時間的経過

表 2 に各群における梗塞巣および border zoneの 広さを示す。

area at risk の広さは，I群，II群，III群と小さ くなる傾向にあったが, 各群間に有意差はなかった。 梗塞壊死巣の大きさはIII群で51.6 $55.8 \% \mathrm{LV}$ と最 も大であり, 以下，II群 $41.5 \pm 5.1 \%$ LV， I 群 29 . $6 \pm 5.2 \% \mathrm{LV}$ の順であった。

border zone は，III群ではほとんど同定できな かったが，I群，II群ではその広がりを同定しえた

(図 3 )。そそのきさは，I群では $25.6 \pm 4.9 \% \mathrm{LV}$ で，II群の $10.7 \pm 6.6 \% \mathrm{LV}$ に比し有琶に大であっ た(表 2).

電顕的には，I 群の梗塞中央部では核クロマチン の margination, 筋原線維の融解・断裂，細胞内浮 腫などが高頻度に認められ，ミトコンドリアは crista の融解，配列の乱れに加えて，不定形封入体 の形成を示した(図 4,5).これに対し, border zone では，筋原線維の弛緩， sarcoplasmic reticulum の 拡大, 脂肪滴の増加，ミトコンドリアの crista の配 列の乱れと matrix の淡明化などの変化を認めた が，ミトコンドリア内に封入体は認められなかった (図 6,7 ).

[実験 II］梗塞巣の大きさに対する propranolol 投与の効果

propranolol の投与時期と梗塞巣の太きさとの関 係は図 8 にみる通りである。対照群に抢ける48時間 後の梗塞巣の大きさは $46.0 \pm 5.5 \%$ LVであったが, 結禁前に propranolol を投与したA群，直後に投与 したB群，および 3 時間後の C 群で泳，それぞれ $25.3 \pm 4.6 \% \mathrm{LV}(\mathrm{P}<0.01), 35.0 \pm 4.1 \% \mathrm{LV}(\mathrm{P}<$ $0.01) ， 36.6 \pm 4.7 \% \mathrm{LV}(\mathrm{P}<0.05)$ で，いずれも 対照群に比し梗塞量が有意に小であった。しかし, 結禁 6 時間後投与のD群では $44.1 \pm 8.5 \% \mathrm{LV}$ で, 対照群に比し減少の傾向はみられたが方の差は有意 ではなかった。また，12時間後に propranolol を投 


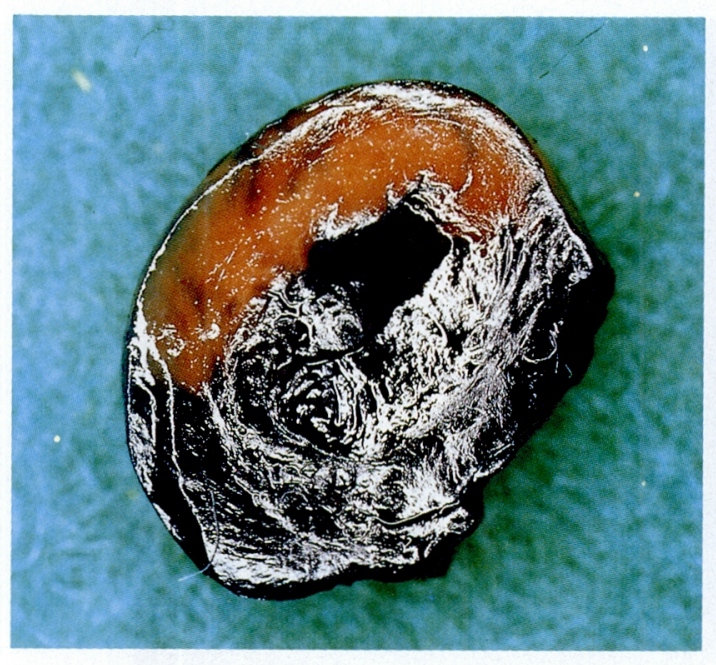

(a) Methylene blue

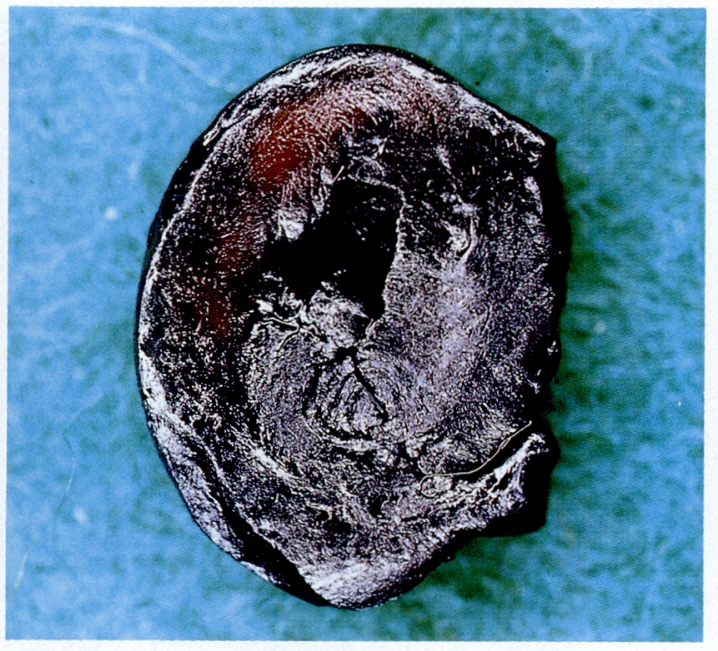

(b) NBT

図 3 I 群の同一断面における Methylene blue 及び NBT 染色

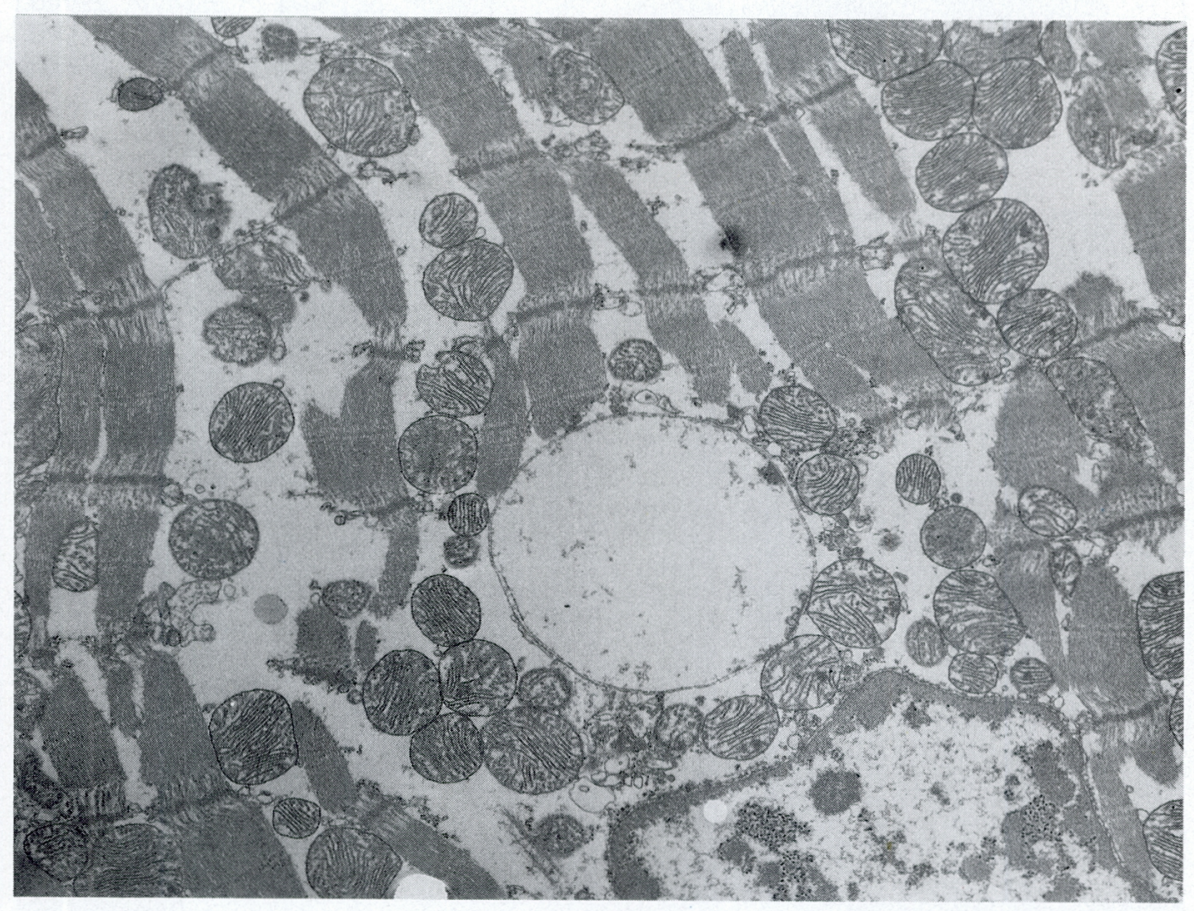

図 4 核クロマチンの margination, 筋原線維の断裂, 細胞内浮腫, ミトコンドリア内の封入体 $(\times 6,200)$ 


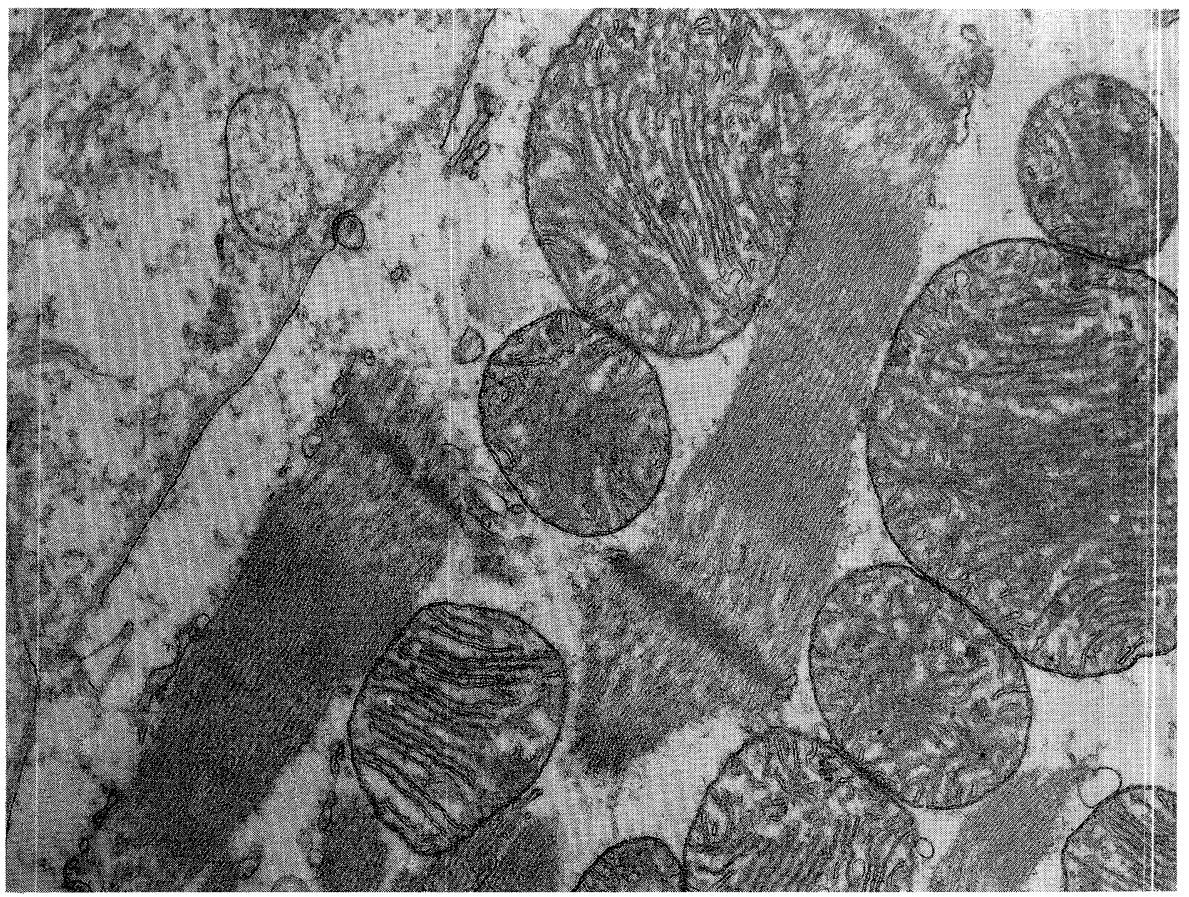

図 5 ミトコンドリア内の封入体 $(\times 17,600)$

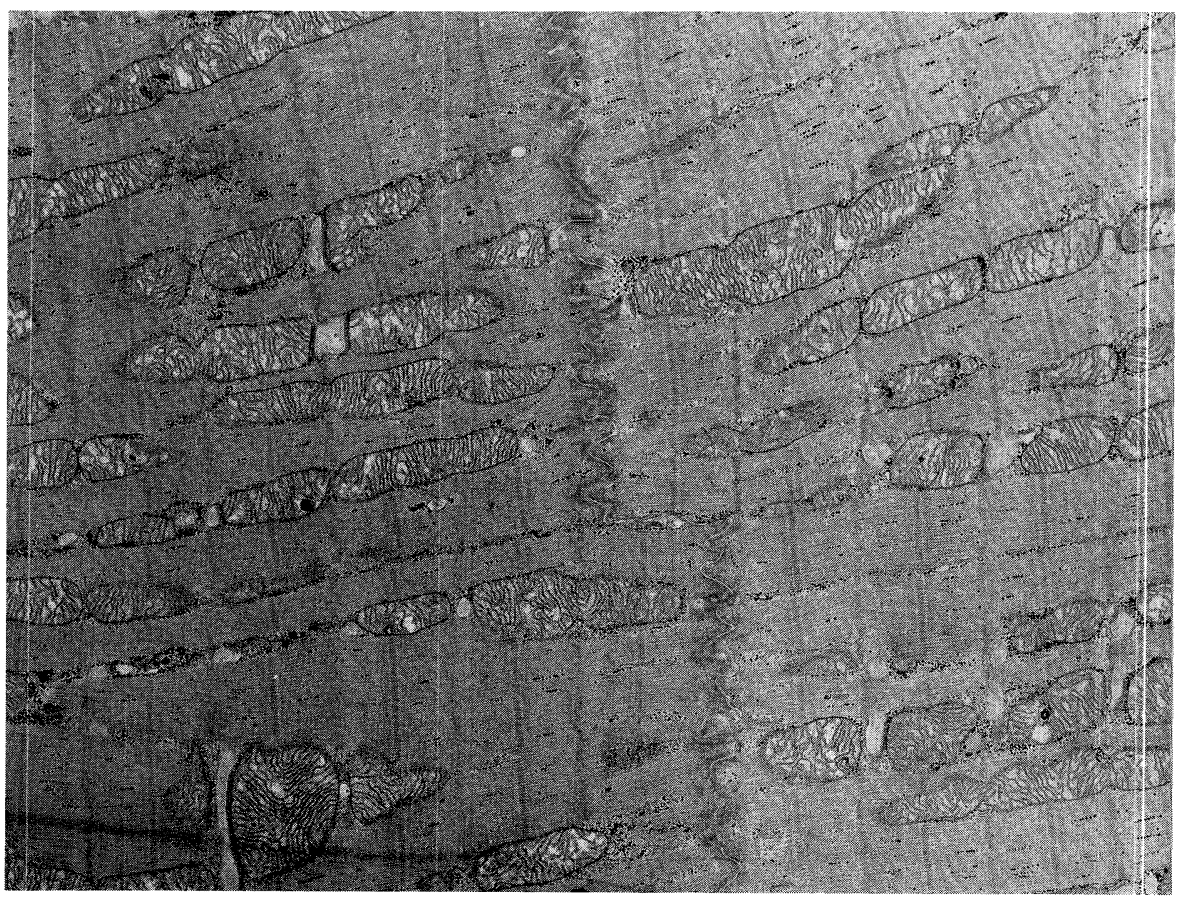

図 6 ミトコンドリアの matrix の淡明化，筋原線維は保たれている $(\times 6,200)$ 


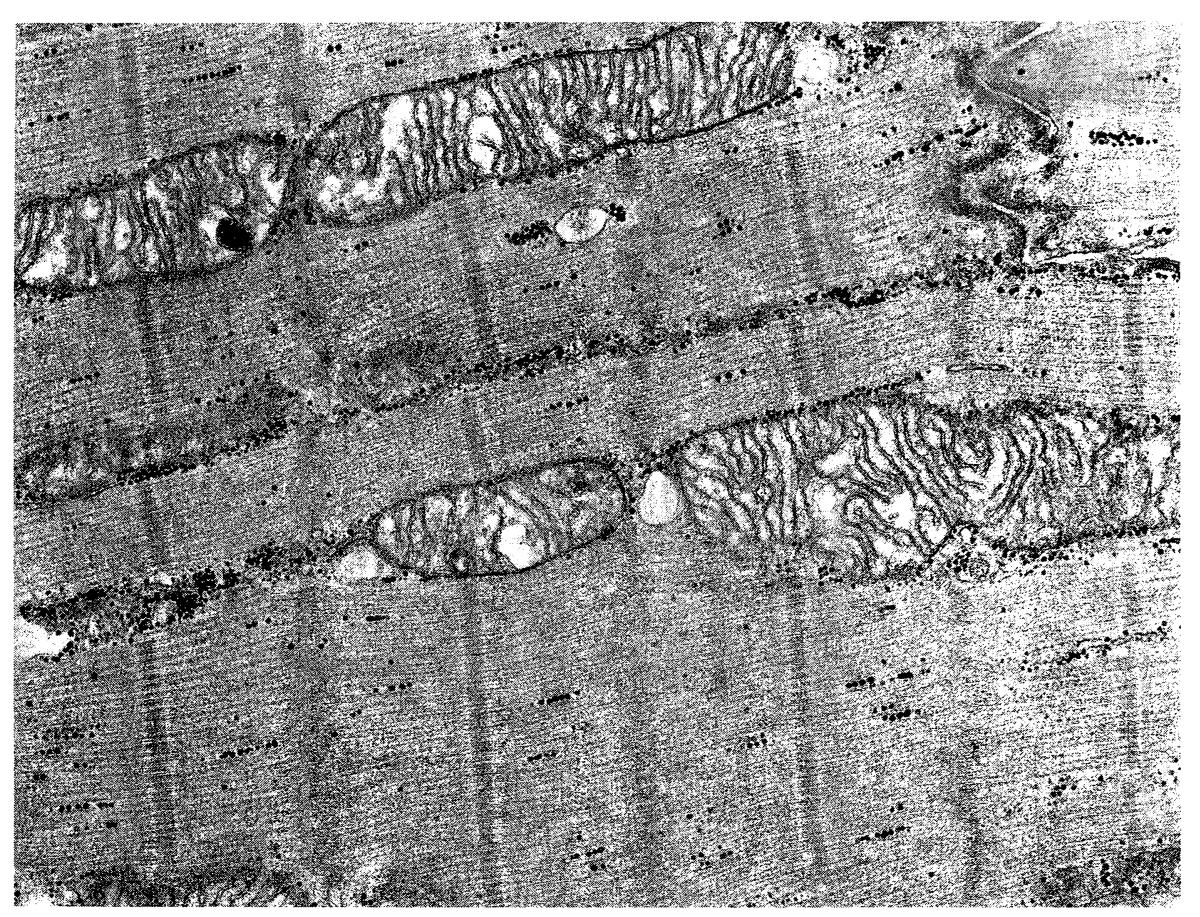

図 7 ミトコンドリアの crystolysis 及び matrix の淡明化 $(\times 17,000)$

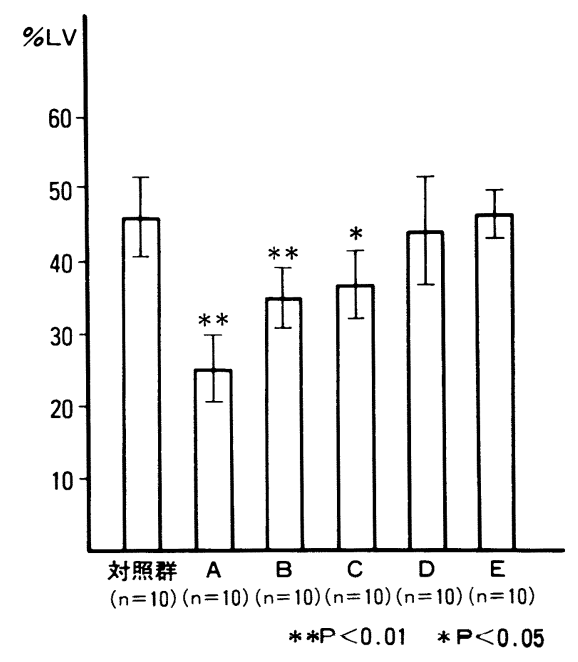

図 8 心筋梗塞巣の大きさ 
表 2 梗塞巣および Border zone の大きさ

\begin{tabular}{|c|c|c|c|c|}
\hline Group & $\begin{array}{c}\text { Time after } \\
\text { occlusion }\end{array}$ & $\begin{array}{c}\text { Area at } \\
\text { risk }(\% \mathrm{LV})\end{array}$ & $\begin{array}{c}\text { Area of } \\
\text { necrosis }(\% \mathrm{LV})\end{array}$ & $\begin{array}{c}\text { Border } \\
\text { zone(\%LV) }\end{array}$ \\
\hline I $(\mathrm{n}=5)$ & $3 \mathrm{hrs}$. & $55.2 \pm 2.6$ & $29.6 \pm 5.2^{*}{ }^{*}$ & $25.6 \pm 4.5$ \\
\hline II $(\mathrm{n}=5)$ & $6 \mathrm{hrs}$. & $52.2 \pm 6.5$ & $41.5 \pm 5.1$ & $10.7 \pm 6.6$ \\
\hline III $(\mathrm{n}=5)$ & $12 \mathrm{hrs}$. & $51.6 \pm 5.8$ & $51.6 \pm 5.8$ & - \\
\hline
\end{tabular}

${ }^{*} \mathrm{P}<0.01$

結紮前
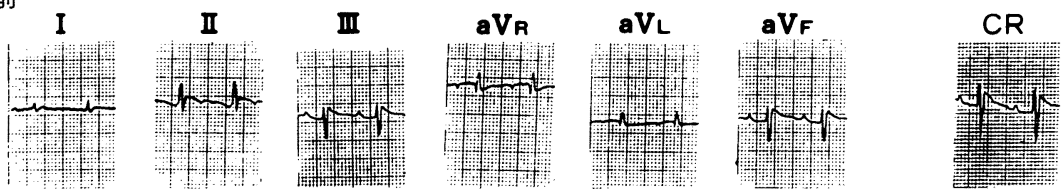

結紮直後
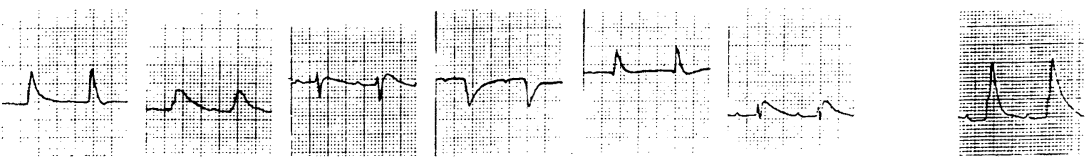

48時間後
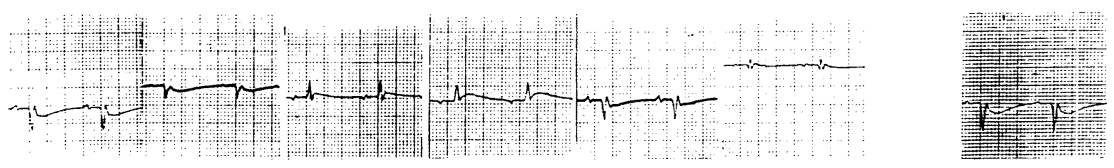

図 9 結禁前後の心電図の変化

与した $\mathrm{E}$ 群では $46.2 \pm 3.6 \% \mathrm{LV}$ であり, 対照群と ほほ同様の值が得られた。なお，A群では B 群，C 群に比し有意に梗塞量が小となっていた $(\mathrm{P}<0.05)$ が, B群とC群の間には有意な差はみられなかった。

各群における心電図の変化は, いずれも図 9 に示 した対照群と同様であり, 結禁直後より前壁〜側壁 誘導で著明な ST 上昇が出現し, 48時間後には同領 域で QS pattern がみられた。

\section{考案}

1971年, Maroko ら³) は, イヌの実験的心筋梗塞 において，冠動脈結禁前あるいは結紮後 3 時間まで に各種薬物を投与すると梗塞病変を小さくすること ができると報告し, 急性心筋梗塞の臨床例において も, 早期に心筋酸素需要を減ずる薬物や冠灌流を増 す薬物を投与することにより梗塞巣の大きさを減ず る可能性があることを指摘した. 以後, 種々の薬物
を投与して梗塞量の縮小をはかる実験的試みが数多 くなされている3,9,16 27).

薬物投与により心筋梗塞巣が縮小するとすれば, 閉塞した冠動脈の灌流域内に，虚血には陥っている が可逆性である部分，すなわち，放置すれば壊死に 宿るが適切な処置によりこれを防止することのでき る reversible ischemic zone (border zone) が存在す るはずである.これまで, 冠動脈の閉塞によって生 ずる虚血野では，血流量あるいは組織学的変化が均 一で border zone は存在しないとする報告もある が28,29)，上記のような border zone の存在を認める 報告の方が多い9 13,30 32). 今回の成績では, 冠動脈結 禁後 6 時間までは無ないし低灌流域と梗塞壊死領域 の差，すなわち border zone が認められたが，12時 間後には肉眼的に確認することはできなかった。こ れは, 冠動脈閉塞 $3 \sim 9$ 時間後まで, 酵素活性の变 失が虚血中央部より遅れている部分が虚血の辺縁部 
に存在するという Fishbein ら ${ }^{10)}$ の報告と一致する. また, NBT 不染部の中心, すなわち壊死中心部とそ の周辺の虚血部における電顕的所見は Gottliebら ${ }^{30}$ の報告とほぼ同様であり，周辺虚血部においては不 可逆性細胞障害を示すミトコンドリア内封入体 ${ }^{33)}$ はみられなかった。このように，結禁 6 時間後にお いても狭いながら border zone が存在していたこと は，心筋梗塞開始後 6 時間以内であれば，冠状動脈 が完全に閉塞した状態であっても, 心筋酸素需要の 減少，エネルギー産生効率増大などをはかることに より, 側副血行その他により心筋細胞の生存に必要 な血流がえられるまで梗塞への進展を遅らせ, 最終 的に梗塞域を縮小しうることを示唆している。

上記の知見に対応して, $\beta$ 遮断薬 propranolol を 投与した際の梗塞巣の大きさに関しては，冠動脈閉 塞後 3 時間あるいは 6 時間までの投与により梗塞巣 を縮小できるとする報告が多い3,4,16 21). しかし， propranolol を冠動脈閉塞前に投与しても心筇障害 汢非投与群と差がなかったとする報告 ${ }^{22)}$ や, 冠動脈 閉塞前の投与では梗塞巣は縮小していたが，閉塞直 後の投与では逆に非投与群よりも病巣が大となると する報告 ${ }^{23)} も$ あり，な打議論がある。そこで，[実験 III により, 冠動脈閉塞前あるいは閉塞後早期の propranolol 投与により梗塞巣が縮小するか否か, 縮小するとすれば閉塞何時間後の投与まで効果を認 わるかを検討した。 その結果, 冠動脈結禁48時間後 に評価した梗塞量では, propranolol $(5 \mathrm{mg} / \mathrm{kg})$ を前 投与した群，閉塞直後あるいは 3 時間後に投与した 群において非投与群に比し有意な梗塞巣の縮小がみ られた。これは, Maroko ら ${ }^{3)}$, Rasmussen ら ${ }^{16)}$, Miura ら ${ }^{17)}$ の成績とほぼ同様であり, かつ今回の border zone に関する成績とも符合していた。 なお， propranolol による梗塞巣縮小の機序については, 心収縮性の低下と心拍数の減少に基づく心筋酸素需 票の減少 $3,34,35)$, 心筋血流の再分布による虚血域への 血流の改善 ${ }^{34)}$, 心内膜下灌流の改善 ${ }^{24)}$, 膜安定化作用 による虚血心筋保護作用 ${ }^{19,25)}$ などが考えられよう。 これまで, 心房ペーシングで心拍数を一定に維持し propranolol を投与しても梗塞巣の縮小が得られた とする報告 ${ }^{3}$, $\beta$ 遮断作用が少なく膜安定化作用が propranolol と同等であるとされている dpropranolol では梗塞巣の縮小が得られなかったと する報告 ${ }^{26)}$ がある。 また， $\beta$ 遮断薬は虚血領域にお ける心筋障害を減じているのではなく, 虚血時に増
加するカテコラミンその他の物質により虚血部に隣 接した領域にまで障害が進展するのを抑えることに よって梗塞巣を縮小するという説もあり ${ }^{36)}$, 作用機 序については現在もなお明らかでない部分が多い.

Peter $ら^{22)}$ は $\beta$ 遮断薬の前投与でも虚血心筋の障 害は減じなかったと報告している.しかし，彼らの 実験は, ラットと異なって冠動脈の側副血行が豊富 なイヌを用いていること, 梗塞量の評価として梗塞 巣全体からの creatine phosphokinase (CPK) depletion ではなく梗塞巣のある一部分からの CPK loss をみていることなど, 対象, 方法が今回のモデ ルとは著しく異なっており, これが結果の相違をも たらした可能性がある，事実，著者と同様ラットを 用いた Kumar ら ${ }^{23)}$ の実験では， $\beta$ 遮断薬の前投与 により有意な梗塞巣の縮小が得られている。なお, 彼らの実験では, 冠状動脈結禁直後の propranolol 投与では梗塞巣はむしろ拡大したというが，これは 梗塞巣の左室に占める重量比を測定した結果であ り, 著者と同様に体積比でみると対照群と不変ない しむしろ減少傾向がみられ，今回の成績に反するも のではない.

今回の実験では, propranolol 投与の梗塞巣の大 きさへの影響を冠動脈結禁 48 時間後に観察した.こ のように48時間後に評価した梗塞巣の縮小が最終的 に完成された梗塞の縮小を意味するのか，あるいは 単に梗塞完成の遅延を意味するのかについては Maclean ら ${ }^{21)}$ の検討があり, propranolol を結紮前 に投与したラットでは 2 日後, 3 週間後の梗塞巣と もに縮小することが報告されている.また, $\beta$ 遮断薬 である mepindolol を結禁前にラットに投与した Chiariello ${ }^{25)}$ の実験でも，2 日後，21日後の梗塞 巣ともに縮小することが認められている。したがっ て, 著者が冠動脈結禁 48 時間後の時点で確認した梗 塞巣の縮小は, 永続的なものと考えられる. イ邓を 用いた実験では, 梗塞巣は縮小するのではなく単に その完成が遅れるだけであるとする報告もある が ${ }^{36,37)}$, これらの実験でも最終的な梗塞巣の評価を 結紮 24 時間後 ${ }^{37)}$, あるいは48時間後 ${ }^{36)}$ に行ってい る.

[実験II] における心電図変化については，結 禁直後の著明な ST 上昇, 48時間後の QS pattern はA〜E群, 対照群のいずれも同様で, 前壁〜側壁 誘導に認められ, 心電図変化の出現する誘導数につ いては各群間に差はなかった。臨床的に心筋梗塞の 
広がりを推定する指標として標準12誘導における心 電図変化，あるいは Q Index などが用いられるが， 小動物のラットでは左冠状動脈の灌流域である前壁 〜側壁において多数の誘導部位から心電図を記録す ることは技術的に困難であり, ラットでは梗塞巣の 拡がりの評洒に心電図を用いるのは不適当と思われ た.

心筋梗塞急性期における $\beta$ 遮断薬の使用は以前か ら試みられて打り,また, $\beta$ 遮断薬は心筋梗塞の長期 予後の改善にも有効といわれている. 今回の実験で は, 発症 3 時間以内の $\beta$ 遮断薬投与は心筋梗塞巣の 拡大を防止する効果があり，急性期におけるその有 効性が裏付けられたものといえよう。近年，心筋梗 塞急性期に，冠動脈の閉塞を除去する積極的な治療 として血栓溶解療法や経皮的冠動脈拡張術が行われ ているが, 今後, これらと本法との併用についても 検討する必要があろう。

\section{総括}

ラットの左冠動脈を結紮して作成した心筋梗塞病 変について, 心筋の壊死病巣, 非梗塞虚血域 (border zone) の大きさの変化を経時的に追究した. また, 結 紮前, 結禁直後, および結紮 $3 ， 6 ， 12$ 時間後に propranolol を投与した際の梗塞壞死巣の大きさの 変化を観察した。結果は以下の通りである.

1. 冠動脈結禁 3 時間後 (I 群), 6 時間後 (II群), 12 時間後 (III群)の 3 群において, methylene blue で染色されない area at risk の心筋領域の大きさ は結紮後時間の経過とともに小となる傾向があっ たが，その差は統計的には有意ではなかった。

2. NBT で染色される心筋壊死の領域は, III群で $51.6 \pm 5.8 \% \mathrm{LV}$ と最も大であり，以下，II群41. $5 \pm 5.1 \%$ LV, I 群 $29.6 \pm 5.2 \%$ LV の順であっ た。一方, methylene blue では染色されないが NBT で染色される border zone は, I 群で $25.6 \pm 4.9 \% \mathrm{LV}$ と最も大きく，II群が $10.7 \pm 6$. 6\% LV でこれにつぎ，III群ではその存在を確認 できなかった。 なお, border zone では, 電顕的 にミトコンドリア内封入体は認められなかった。

3. 冠動脈結紮前, 結禁直後または結紮 3 時間後に propranolol を投与した時の心筋梗塞の大きさ は，それぞれ $25.3 \pm 4.6 \% \mathrm{LV} ， 35.0 \pm 4.1 \% \mathrm{LV}$, $36.6 \pm 4.7 \%$ LV であり, 対照群の $46.0 \pm 5.5 \%$ LV に比し有意に小であった。これに対し，結禁
後 6 または12時間に propranolol を投与した群の 心筋壊死巣の大きさはそれぞれ $4.4 .1 \pm 8.5 \%$ LV， 46.2 $23.6 \% \mathrm{LV}$ であり, 対照群との間に有 意差はなかった。

4. 以上のごとく, 冠動脈結禁後少なくとも 6 時間 までは，心筋に area at risk ではあるが梗塞壞死 に陷っていない部位，すなわち border zone（非 梗塞虚血域）が認められ，また，結禁後 3 時間以 内に propranolol を投与すると梗塞壊死巣をコン トロールに比して小範囲にとどめることができ る.したがって, 心筋梗塞発症早期の $\beta$ 遮断薬投与 は心筋保護に有効であると考えられる。

\section{謝辞}

稿を終えるに臨み御指導と御校閲を賜り肫した群馬大 学第二内科学教室村田和彦教授, 鈴木 忠講師, 神田 洋 博士に深謝いたします。

\section{文献}

1) Page, D.L., Caufield, J.B., Kastor, J.A., DeSanctis, R.W., Sanders, C.A.: Myocardial changes associated with cardiogenic shock. N. Engl. J. Med., 285 : 133-137, 1971.

2) Harnarayan, C., Bennett, M.A., Pentecost, B. L., Brewer, D.B. : Quantitative study of infarcted myocardium in cardio६enic shock. Br. Heart J., 32 : 728-732, 1970.

3) Maroko, P.R., Kjekshus, J.K., Sobel, B.E., Watanabe, T., Covell, J.W., Ross, J., Braunwald, E. : Factors influencing infarct size following experimental coronary artery occlusions. Circulation, 43:67-82, 1971.

4) Maroko, P.R., Braunwald, E. : Modification of myocardial infarction size after coronary occlusion. Ann. Int. Med., 79 : 720733, 1973.

5) Braunwald, E., Maroko, P.R. : The reduction of infarct size - an idea whose time (for testing) has come. Circulation, 50:206-209, 1974.

6) Hearse, D.J., Yellon, D.M., Dovwney, J.M. : Can beta blockers limit myocardial infarct size? Europ. Heart J., 7 : 925-930, 1986.

7) Yusuf, S.: Interventions that potentially 
limit myocardial infarct size: Overview of clinical trials. Am. J. Cardiol., 60 : 11A-17A, 1987.

8) Sleight, P. : Beta blockade early in acute myocardial infarction. Am. J. Cardiol., 60 : 6A-10A, 1987.

9) Hearse, D.J., Opie, L.H., Katzeff, I.E., Lubbe, W.F., van Der Werff, T.J., Peisach, M., Boulle, G. : Characterization of the "border zone" in acute regional ischemia in the dog. Am. J. Cardiol., 40 : 716-726, 1977.

10) Fishbein, M.C., Hare, C.A., Gissen, S.A., Spadaro, J., Maclean, D., Maroko, P.R. : Identification and quantification of histochemical border zone during the evolution of myocardial infarction in the rat. Cardiovasc. Res., $14: 41-49,1980$.

11) Cox, J.L., McLaughlin, V.W., Flowers, N.C., Horan, L.G. : The ischemic zone surrounding acute myocardial infarction. Its morphology as detected by dehydrogenase staining. Am. Heart J., 76 : 650-659, 1968.

12) Reimer, K.A., Lowe, J.E., Rasmussen, M.M., Jennings, R.B. : The wavefront phenomenon of ischemic cell death 1.Myocardial infarct size vs duration of coronary occlusion in dogs. Circulation, $56: 786-794,1977$.

13) Darsee, J.R., Kloner, R.A. : Demonstration of lateral and epicardial border zone salvage by flurbiprofen using an in vivo method for assessing myocardium at risk. Circulation, $63: 29-35,1981$.

14) Selye, H., Bajusz, E., Grasso, S., Mendell, P. : Simple techniques for the surgical occlusion of coronary vessels in the rat. Angiology, $11: 398-407,1960$.

15) Nachlas, M.M., Shnitka, T.K.: Macroscopic identification of early myocardial infarcts by alterations in dehydrogenase activity. Am. J. Pathol., 42 : 379-396, 1963.

16) Rasmussen, M.M., Reimer, K.A., Kloner, R. A., Jennings, R.B. : Infarct size reduction by propranolol before and after coronary ligation in dogs. Circulation, 56:794-798,
1977.

17) Miura, M., Thomas, R., Ganz, W., Sokol, T., Shell, W.E., Toshimitsu, T.,Kwan, A.C., Singh, B.N.: The effect of delay in propranolol administration on reduction of myocardial infarct size after experimental coronary artery occlusion in dogs. Circulation, $59: 1148-1157,1979$.

18) Hillis, L.D., Askenazi, J.,Radvany, P., Muller, J.E., Fishbein, M.C., Maroko, P.R. : Use of changes in the epicardial QRS complex to assess interventions which modify the extent of myocardial necrosis following coronary artery occlusion. Circulation, $54: 591-598$, 1976.

19) Reimer, K.A., Rasmussen, M.M., Jennings, R. B. : Reduction by propranolol of myocardial necrosis following temporary coronary artery occlusion in dogs. Circ. Res., 33 : 353-363, 1973.

20) Ergin, M.A., Dastgir, G.,Butt, K.M.H., Stuckey, J.H. : Prolonged epicardial mapping of myocardial infarction: The effects of propranolol and intra-aortic balloon pumping following coronary artery occlusion. J. Thorac. Cardiovasc. Surg., $72:$ 892-899, 1976.

21) Maclean, D., Fishbein, M.C., Braunwald, E., Maroko, P.R. : Long-term preservation of ischemic myocardium after experimental coronary artery occlusion. J. Clin. Invest., $61: 541-551,1978$.

22) Peter, T., Heng, M.K., Singh, B.N., Ambler, P., Nisbet, H., Elliot, R., Norris, R.M. : Failure of high doses of propranolol to reduce experimental myocardial ischemic damage. Circulation, 57 : 534-540, 1978.

23) Kumar, C., Singh, M.: Pharmacological interventions and myocardial infarct size in rat. Europ. J. Pharmacol., 109 : 117-120, $198 \overline{.}$.

24) Becker, L.C., Fortwin, N.J., Pitt, B. : Effect of ischemia and anti-anginal drugs on the distribution of radioactive microspheres in the canine left ventricle. Circ. Res., $28: 263$ 269. 1971. 
25) Chiariello, M., Ambrosio, G., CappelliBigazzi, M., Perrone-Filardi, P., Tritto, I., Condorelli, M.: Mepindolol reduces myocardial necrosis in rats with coronary artery occlusion. J. Cardiovasc. Pharmacol., 7 : 525531, 1985.

26) Reimer, K.A., Rasmussen, M.M., Jennings, R. B.: On the nature of protection by propranolol against myocardial necrosis after temporary coronary occlusion in dogs. Am. J. Cardiol., 37 : 520-527, 1976.

27) Richard, V., de Leiris, J.: Reduction of myocardial infarct size in rats under the effect of bepridil. Adv. Myocardial., 6 : 563572, 1985.

28) Marcus, M.L., Kerber, R.E., Ehrhardt, J., Abboud, F.M.: Three dimensional geometry of: acutely ischemic myocardium. Circulation, $52: 254-263,1975$.

29) Factor, S.M., Sonnenblick, E.H., Kirk, E.S. : The histologic border zone of acute myocardial infarction: islands or peninsulas ? Am. J. Pathol., 92 : 111-124, 1978.

30) Gottlieb, G.J., Kubo, S.H., Alonso, D.R. : Ultrastractural characterization of the border zone surrounding early experimental myocardial infarcts in dogs. Am. J. Pathol., $103:$ 292-303, 1981.

31) Darsee, J.R., Kloner, R.A. : Dependency of location of salvageable myocardium on type of intervention. Am. J. Cardiol., 43: 702-710, 1981.

32) Mitsunami, K., Fukuhara, T., Kato, S., Bito, K., Kinoshita, M., Kawakita, S.: The border zone in acute myocardial ischemia in the dog $-\mathrm{A}$ histochemical, biochemical, and ultrastractural study-Jpn. Circ. J., 48 : 18-31, 1984.

33) Jennings, R.B., Ganote, C.E. : Structural changes in myocardium during acute ischemia. Circ. Res., 34, 35, Suppl. 3 : 156-168, 1974.

34) Vatner, S.F., Baig, H., Manders, W.T., Ochs, H. : Effects of propranolol on regional myocardial function, electrograms, and blood flow in conscious dogs with myocardial ischemia. J. Clin. Invest., 60:353-360, 1977.

35) Kloner, R.A., Braunwald, E. : Observations on experimental myocardial ischaemia. Cardiovasc. Res., $14: 371-395,1930$.

36) Bullock, G.R., Lepran, I., Parratt, J.R., Szekeres, L., Wainwright, C.L. : Effects of a combination of metoprolol and dazmegrel on myocardial infarct size in rats. Br. J. Pharmacol., 86 : 235-240, 1985.

37) Chambers, D.E., et al. : Effects of flurbiprofen in altering the size of myocardial infarcts in dogs : reduction or delay? Am. J. Cardiol., $51: 884-890,1983$. 


\title{
EFFECT OF PROPRANOLOL ON THE INFARCT SIZE AND EXTENT OF THE BORDER ZONE IN CORONARY LIGATED RATS
}

\author{
SHIGERU OHSHIMA
}

\author{
The Second Department of Internal Medicine, Gunma \\ University School of Medicine, Maebashi, Japan \\ (Director: Prof. Kazuhiko Murata)
}

The present study was attempted in order to investigate the effectiveness of propranolol in limiting of myocardial infarct size following ligation of the left coronary artery in Wistar rats. The non-infarcted ischemic zone, the border zone, was significantly larger in the rats sacrificed 3 hours after the ligation $(25.6 \pm 4.9 \% \mathrm{LV})$ than in those sacrificed 6 hours after ligation $(10.7 \pm$ $6.6 \% \mathrm{LV})$. No border zone was demonstrated when the rats were sacrificed 12 hours after the ligation. Nor were any differences in the size of the area at risk found among the above 3 groups. The size of the infarcted area was significantly smaller than in the control group (46. $0 \pm 5.5 \% \mathrm{LV})$ when propranolol was administered intraperitoneally before $(25.3 \pm 4.6 \% \mathrm{LV})$, immediately after $(35.0 \pm 4.1 \% \mathrm{LV})$ or 3 hours after ligation $(36.6 \pm 4.7 \% \mathrm{LV})$. However, propranolol could not reduce infarct size when administered 6 hours $(44.1 \pm 8.5 \% \mathrm{LV})$ or 12 hours $(46.2 \pm 3.6 \% \mathrm{LV})$ after ligation of the coronary artery.

The present study clearly demonstrates the presence of a non-infarcted ischemic zone, a border zone, until at least 6 hours after the ligation of the coronary artery and reduction of the infarcted area by propranolol when administered until at least 3 hours after the ligation. Thus, the author postulated the usefulness of beta-blocking agents in the early phase of acute myocardial infarction.

Key words: Myocardial infarction, Border zone, Propranolol 